\title{
THE EFFECT OF TEAMS ACHIEVEMENT DIVISION METHOD ON KNOWLEDGE AND ATTITUDE TO PREVENT SMOKING CESSATION AMONG ELEMENTARY SCHOOL CHILDREN IN KUPANG CITY, INDONESIA
}

\author{
Riny Pujiyanti ${ }^{1}$, Budi Utomo ${ }^{2}$, Padoli $^{3}$ \\ 1 Faculty of Nursing, Airlangga University, Mulyorejo Street 60115, Surabaya, Indonesian \\ 2 Faculty of Medicine, Airlangga University, Surabaya, Indonesian \\ 3 Health Ministry Polytechnic of the Ministry of Health in Surabaya, Indonesia \\ * Correspondence: pujiyantiriny@gmail.com
}

\begin{abstract}
Smoking behavior in elementary school children is one of the behaviors that can cause chronic problems or diseases in adulthood, the younger a person's smoking age, the higher the risk of becoming a heavy smoker and chronic illness. Health education both at home, school, and the playing environment are critical given because health education is one of the main factors in changing or increasing one's knowledge, attitudes, and actions. The method of health education that can be given to school children with a small group target is by using the cooperative learning method, one of which is the Student Teams Achievement Division (STAD) method. This study aims to analyze the effect of the STAD method on knowledge and attitude of smoking prevention among elementary school children. This study used a quasi-experimental design pre and post-test with an equivalent control group. The samples in the study were 68 primary school children in Kupang City Elementary School that were obtained using simple random sampling. The results showed there is a significant difference in knowledge before after receiving the STAD method $(p=0,000)$. Another result also showed that there was a positive effect of STAD method on attitude of participants in the experimental group $(p=0,000)$. The recommendation of this study is for health workers to be able to provide health education using the STAD method in elementary school children. Parents and teachers can play an active role in increasing children's understanding of smoking prevention.
\end{abstract}

Keywords: student teams achievement, knowledge, attitude, smoking prevention, elementary school children

International Journal of Nursing and Health Services (IJNHS), September 2019, Volume 2, Issue 3; Page 107-115

Received: 28 June 2019; Revised: 18 July 2019; $\quad$ Accepted: 23 July 2019

DOI: http//doi.org/10.35654/ijnhs.v2i3.175

\section{Introduction}

Smoking behavior in elementary school children is one of the behaviors that can cause chronic problems or diseases in adulthood, the younger the smoking age of a person, the higher the risk of becoming a heavy smoker and chronic illness (1). In various regions in Indonesia, there are still a number of elementary school children who smoke when they are in the school environment. This is evident from the increasing prevalence of early smoking at the age of 10-18 years in Indonesia (2). Increasing the incidence of the old age of tobacco will also increase cigarette users, which in turn will 
have an impact on the higher burden of smoking-related illnesses and the increase in mortality due to smoking. Smoking can cause not only a health burden but also a social, economic, and environmental burden for active smokers and other people (passive smoking) (3).

The Tobacco Atlas 6th edition exposes the country to the most cigarette users in the world to China, India, and Indonesia (4). The death rate continues to increase, and it is estimated that by 2030, the death rate from the world will reach 10 million (3). The 2014 Global Youth Tobacco Survey (GYTS) states that Indonesia is the age of 12-13 years (3). The initial period of smoking in East Nusa Tenggara at the age of 5-9 years as much as $0.9 \%$ and the age of $10-14$ years as much as $13.1 \%$ (5). The results of the latest 2018 Risks of the state that smoking prevalence of age 10-18 years increased by $1.9 \%$ from $7.2 \%$ in Riskesdas 2013 to $9.1 \%$ (2).

The desire to initiate smoking occurs at school age, so the prevention of tobacco becomes content that can be integrated into school curricula and regulations (6). Prevention of dangerous behaviors such as smoking in schools is a matter that needs to be done but is not a program for schools that never produce the expected results (6). The majority of applications in adolescence are developed in schools by making the program one of the components of broad tobacco use control programs (7).

Factors that influence someone to smoke want to appear "slang" and are considered adults by other people, loyal friends, the wrong perception that smoking can be relieved stress, an environment exposed to cigarettes (parents and peer friends), expels saturation (3). Adult child social environment allows children to form perceptions, motivations, and social learning about cigarettes or tobacco. Close friends can play an essential role in a child's vulnerability to tobacco use; for example, the user group has to start learning and following behavioral patterns and adopting cigarette use (8).

Preventive action is an effort that can be done to prevent the use of cigarettes in the community, especially in children. Preventive efforts can be made by health care providers, especially community nurses, namely by providing advice, health education, counseling, or preventive measures to avoid the use of cigarettes and other tobacco products (8). Health education both at home, school, and playing because it is one of the main factors in changing one's knowledge, attitudes, and actions. These things should be considered by various parties, such as parents or family, teachers, and themselves (9). The level of primary education is active and positive living habits so that health education at the elementary school level needs to be prioritized (10).

Health education methods that can be given to schoolchildren with a small group target, namely by using the cooperative learning method. The type of collaborative learning that can be applied is through group discussion using the cooperative learning approach of the Student Teams Achievement Division (STAD) type. STAD is a small group learning method (4-5 people) that emphasizes activities and interactions between students to motivate each other and help each other in mastering learning material to achieve maximum achievement (11). Every child has the same opportunity to contribute to improving his performance through collaboration and the active role of each member. The STAD method has been widely used as a method of learning primary education in the classroom and shows results that are more effective than conventional learning (12). Learning using the STAD method shows an increase in thinking skills, knowledge, activities and learning outcomes, social attitudes, and student achievement (13-17). 
Based on the above problems, this study wants to see the effectiveness of the STAD method health education on smoking prevention knowledge and attitudes in elementary school children in Kupang City.

\section{Objectives}

The study aimed to examine the effect of the Student Teams Achievement Division (STAD) method on knowledge and attitude to prevent smoking cessation among elementary school children in Kupang City.

\section{Method}

This study used a quasi-experimental design pre and post-test with an equivalent control group. This study was conducted at Kupang City Elementary School on March 19-April 30, 2019. The sampling technique in this study used probability sampling by simple random sampling, namely determination randomly selected samples withdraws. Sixtyeight samples were recruited from elementary school who had no smoked. The research instrument for measuring children's knowledge and attitudes about smoking prevention was modified from the Global Youth Tobacco Survey questionnaire containing 12 questions on the knowledge questionnaire and ten questions on the attitude questionnaire.

The STAD method consists of five main procedures, which include presenting classes; assign students in groups; tests and quizzes; giving individual improvement scores; group awards. STAD has a research instrument in the form of an activity event unit (SAK), discussion sheet, and quiz sheet made by the researcher based on a theoretical review of smoking behavior. The STAD method is carried out in 2 learning times per week for 50 minutes/lesson. The activity starts with introducing and contracting time and conveying actions (intervention) procedures. Delivering material about smoking prevention includes the notion of smoking behavior, influencing factors, content in a cigarette, the impact of smoking on health, and efforts to prevent smoking. After delivering the material, respondents were divided into seven groups consisting of 4-5 respondents. Each group is given a group discussion sheet in the form of a topic discussed together in the group. After reviewing the topic given, representatives from each group presented the results of the discussion. The next step, the respondent is given an individual quiz sheet that is done in the group. The researcher assisted by the facilitator collected the quiz sheet, which was then assessed. The group that gets the highest score is given a reward.

Analysis of the data used was univariate analysis and bivariate analysis using the Wilcoxon and Mann Whitney tests with significance level $\alpha<0.05$.

\section{Result}

A frequency distribution is based on the effect of the STAD method on smoking prevention knowledge and attitudes in the intervention and control groups. Complete data can be seen in table 1 . 
Table 1: Frequency Distribution Based on Characteristics of Respondents

\begin{tabular}{|c|c|c|c|c|}
\hline \multirow[t]{2}{*}{ Characteristics of Respondents } & \multicolumn{2}{|c|}{$\begin{array}{c}\text { Intervention Group } \\
(\mathrm{n}=34)\end{array}$} & \multicolumn{2}{|c|}{$\begin{array}{c}\text { Control Group } \\
(n=34)\end{array}$} \\
\hline & $\mathbf{f}$ & $\%$ & f & $\%$ \\
\hline \multicolumn{5}{|l|}{ Usia } \\
\hline Nine years & 9 & 26,5 & 12 & 35,3 \\
\hline Ten years & 15 & 44,1 & 18 & 52,9 \\
\hline 11 years & 10 & 29,4 & 4 & 11,8 \\
\hline \multicolumn{5}{|l|}{ Family members smoke } \\
\hline Yes & 22 & 64,7 & 23 & 67,6 \\
\hline No & 12 & 35,3 & 11 & 32,4 \\
\hline \multicolumn{5}{|l|}{ Smoking inside the house } \\
\hline Yes & 16 & 72,7 & 21 & 91,3 \\
\hline No & 6 & 27,3 & 2 & 8,7 \\
\hline \multicolumn{5}{|l|}{ Friend smoking behavior } \\
\hline Yes & 11 & 32,4 & 13 & 38,2 \\
\hline No & 23 & 67,6 & 21 & 61,8 \\
\hline \multicolumn{5}{|l|}{$\begin{array}{l}\text { Smoking behavior in the school } \\
\text { environment } \\
\text { See teachers smoking }\end{array}$} \\
\hline Yes & 5 & 14,7 & 1 & 2,9 \\
\hline No & 29 & 85,3 & 33 & 97,1 \\
\hline \multicolumn{5}{|l|}{ There is a smoking ban } \\
\hline Yes & 34 & 100 & 34 & 100 \\
\hline No & 0 & 0 & 0 & 0 \\
\hline \multirow{2}{*}{\multicolumn{5}{|c|}{$\begin{array}{l}\text { Information source } / \text { cigarette } \\
\text { advertisement } \\
\text { Ever seen cigarette advertisements }\end{array}$}} \\
\hline & 20 & 58,8 & & 97,1 \\
\hline No & 14 & 41,2 & 1 & 2,9 \\
\hline \multicolumn{5}{|l|}{ Ad source } \\
\hline Television & 17 & 85 & 23 & 69,7 \\
\hline Poster / Billboards & 2 & 10 & 5 & 15,1 \\
\hline Social media & 0 & 0 & 2 & 6,1 \\
\hline Newspaper & 1 & 5 & 3 & 9,1 \\
\hline \multirow{2}{*}{\multicolumn{5}{|c|}{$\begin{array}{l}\text { Sources of information on the dangers of } \\
\text { smoking } \\
\quad \text { Ever seen/got information }\end{array}$}} \\
\hline & & & & \\
\hline Yes & 28 & 82,4 & 24 & 70,6 \\
\hline No & 6 & 17,6 & 10 & 29,4 \\
\hline \multicolumn{5}{|l|}{ Resources } \\
\hline Health workers & 5 & 17,9 & 8 & 33,3 \\
\hline Television & 16 & 57,1 & 10 & 41,6 \\
\hline Poster / Billboards & 3 & 10,7 & 3 & 12,5 \\
\hline Newspapers / Magazines & 2 & 7,1 & 1 & 4,2 \\
\hline Social media & 2 & 7,1 & 2 & 8,3 \\
\hline
\end{tabular}

Based on table 1. It can be seen that univariate results were obtained in the control group, most of the respondents were ten years old (52.9\%), and in the intervention group, almost half was ten years old (44.1\%). Most of the respondents in both the control and intervention groups had parents/family members at home who smoked $(67.6 \%$ and $64.7 \%)$ and the smoking behavior was carried out inside the house in the control group (91.3\%) and in the intervention group (72.7\%). Although most of the respondents had friends who did not smoke, in both the control and intervention 
groups, almost half of the respondents still had friends who smoked (38.2\% and $32.4 \%$ ). Both groups had a smoking ban in school, so in general, respondents never saw their teacher smoke in the school environment, namely in the control group (97.1\%) and in the intervention group (85.3\%). Information/advertisement of cigarette products, in general, has been seen by respondents in the control group (97.1\%) and in the intervention group, most respondents (58.8). The source of information came from television in the control group (69.7\%) and in the intervention group (85\%). Information about the dangers of smoking has also been seen or obtained by respondents both in the control group (70.6\%) and the intervention group $(82.4 \%)$ through television media (41.6\%) in the control group and (57.1\%) in the intervention group.

Table 2: The distribution of the level of knowledge about smoking prevention in the intervention group and the control group before (pre) and after (post) was given the STAD method in elementary school children in the city of Kupang

\begin{tabular}{|c|c|c|c|c|c|c|c|c|}
\hline \multirow{2}{*}{ Knowledge } & \multicolumn{4}{|c|}{ Intervention } & \multicolumn{4}{c|}{ Control } \\
\cline { 2 - 10 } & \multicolumn{2}{|c|}{ Pre } & \multicolumn{2}{c|}{ Post } & \multicolumn{2}{c|}{ Pre } & \multicolumn{2}{c|}{ Post } \\
\cline { 2 - 9 } & $\mathrm{f}$ & $\%$ & $\mathrm{f}$ & $\%$ & $\mathrm{f}$ & $\%$ & $\mathrm{f}$ & $\%$ \\
\hline Well & 2 & 5,88 & 31 & 91,18 & 1 & 12,22 & 2 & 5,88 \\
\hline Enough & 12 & 35,29 & 3 & 8,82 & 13 & 38,23 & 11 & 32,35 \\
\hline Less & 20 & 58,82 & 0 & 0 & 20 & 58,82 & 21 & 61,76 \\
\hline Total & 34 & 100 & 34 & 100 & 34 & 100 & 34 & 100 \\
\hline
\end{tabular}

Based on table 2, it can be seen that the distribution of the results of the pre-test in the treatment group and the control group showed that most had less knowledge $(58.82 \%)$. The post-test results showed a change in the treatment group after being given the STAD method intervention, where there was a change in the level of knowledge, namely in general respondents had good experience $(91.18 \%)$ and sufficient knowledge (8.82\%), whereas in the control group there was little knowledge increase is in the excellent category (5.88), the decline in the class is entirely $(32.35 \%)$, and the type is less (61.76\%).

Table 3: The method for elementary school children in Kupang City is the level of knowledge about smoking

\begin{tabular}{lccccc}
\hline Variables & \multicolumn{2}{c}{ Control group } & \multicolumn{4}{c}{ Intervention group } & \\
& Mean & SD & Mean & SD & P \\
\hline $\begin{array}{l}\text { Pretest of } \\
\text { knowledge }\end{array}$ & 6,02 & 1,7835 & 6,23 & 1,8919 & 0,034 \\
$\begin{array}{l}\text { Posttest of } \\
\text { knowledge }\end{array}$ & 6,17 & 1,8824 & 8,45 & 1,0066 & 0,000 \\
\hline
\end{tabular}

The data in table 3 shows that the results of the analysis of knowledge data in the treatment group with Wilcoxon signed test obtained a value of $p=0,000<0,05$, meaning that there were significant differences in the pretest and posttest knowledge about smoking prevention in the treatment group given the health education method STAD. While the results of data analysis in the control group with the Wilcoxon signed, test obtained a value of $p=0.034<0.05$, meaning that there are differences in the amount of the pre-test and post-test knowledge about smoking prevention. The Mann Whitney test results obtained $p=0,000<0,05$, which means there is a difference in knowledge about 
smoking prevention between the control group and the treatment group. Thus it can be stated that the health education method of the STAD affects the level of knowledge about smoking prevention in primary school children in Kupang City.

Table 4: Distribution of attitudes about prevention of smoking in the treatment and control groups before (pre) and after (post) given the STAD method in elementary school children in Kupang City

\begin{tabular}{|c|c|c|c|c|c|c|c|c|}
\hline \multirow{2}{*}{ Attitude } & \multicolumn{4}{|c|}{ Intervention } & \multicolumn{4}{c|}{ Control } \\
\cline { 2 - 9 } & \multicolumn{2}{|c|}{ Pre } & \multicolumn{2}{|c|}{ Post } & \multicolumn{2}{c|}{ Pre } & \multicolumn{2}{c|}{ Post } \\
\cline { 2 - 9 } & $\mathrm{f}$ & $\%$ & $\mathrm{f}$ & $\%$ & $\mathrm{f}$ & $\%$ & $\mathrm{f}$ & $\%$ \\
\hline Positive & 13 & 38,24 & 29 & 85,29 & 11 & 32,35 & 12 & 35,29 \\
\hline Negative & 21 & 61,76 & 5 & 14,71 & 23 & 67,64 & 22 & 64,70 \\
\hline Total & 34 & 100 & 34 & 100 & 34 & 100 & 34 & 100 \\
\hline
\end{tabular}

Based on table 4, it can be seen that the distribution of the results of the pre-test showed that most had negative attitudes, namely in the control group (67.64\%) and the treatment group (61.76\%). The post-test results showed a change in the treatment group after being given the STAD method intervention, where there was a change in attitude, in general respondents had a positive attitude (85.29\%), while in the control group the majority of respondents had a negative attitude (64.70\%).

Table 5: Attitudes about smoking prevention in the treatment and control groups before (pre) and after (post) were given the STAD method for elementary school children in Kupang City

\begin{tabular}{|c|c|c|c|c|c|}
\hline \multirow[t]{2}{*}{ Variables } & \multicolumn{2}{|c|}{ Control group } & \multicolumn{2}{|c|}{ Intervention group } & \multirow[b]{2}{*}{$P$} \\
\hline & Mean & SD & Mean & SD & \\
\hline $\begin{array}{l}\text { Pretest of } \\
\text { attitude }\end{array}$ & 4,32 & 1,6827 & 4,58 & 1,9402 & 0,305 \\
\hline $\begin{array}{l}\text { Posttest of } \\
\text { attitude }\end{array}$ & 4,26 & 1,273 & 8,38 & 2,1179 & 0,000 \\
\hline
\end{tabular}

The data in table 5 shows that the results of attitude data analysis in the treatment group with Wilcoxon signed test obtained a value of $p=0,000<0,05$, which means there are differences in the amount of pre-test and post-test attitudes about smoking prevention that are significant in the treatment group STAD. While the results of data analysis in the control group with the Wilcoxon signed test obtained a value of $p=$ $0.305>0.05$, meaning that there was no difference in the value of the pre-test and posttest attitudes about smoking prevention. The Mann Whitney test results obtained $\mathrm{p}=$ $0,000<0,05$, which means there are differences in attitudes about the prevention of smoking between the control group and the treatment group. Thus it can be stated that the health education method of the STAD has an effect on attitudes about smoking prevention in elementary school children in Kupang City.

\section{Discussion}

Based on the results of the study, before being given the STAD intervention, most children had insufficient knowledge. Data on child characteristics shows that almost 
half of children aged ten years, nearly half are aged nine years and 11 years. Most children have household members who smoke and have smoking behavior in the house. The school applies a smoking ban in the school environment, so in general, children never see their teacher smoke in the school environment. Most children have recognized Information/advertisements on cigarette products through television, posters/billboards, and newspapers. In general, children have also seen or received information about the dangers of smoking through television, health workers, posters/billboards, newspapers/magazines, and social media.

Knowledge is the result of knowing, and this happens after people make observations of particular objects. Sensing occurs through the five human senses, namely the senses of sight, hearing, smell, taste, touch. Most human knowledge is obtained through the eyes and ears (9). Insufficient awareness about the prevention of smoking can be caused by the lack of exposure of children to information on smoking prevention, parenting style of parents, parental behavior that provides an illustration of tobacco in the home to children (18). According to Yang, Sloyd, and Tanner (2019), children's knowledge can be influenced by mass media, parents, and the environment (play and school). Exposure to parents and peers who smoke becomes a form of example to children about smoking behavior, which is considered as a reasonable thing to do and is not dangerous (19).

Based on the results of research conducted in the STAD intervention group, significant results were obtained were, in general, the post-test results showed an increase in the level of knowledge of the response being good. This is influenced by the provision of health education, which, according to Lawrence Green, states that the increase in culture can be done by providing health education using the right method. The Student Teams Achievement Division cooperative learning model is one type of cooperative that emphasizes the existence of activities and interactions between students to motivate each other and help each other in mastering the subject matter to achieve maximum achievement (12). Previous research shows an increase in thinking skills, knowledge, activities and learning outcomes, social attitudes, and student achievement (13-17).

Increased knowledge of children is caused because at the stage of class presentation children are given initial information about smoking prevention behaviors including understanding and factors that influence smoking behavior, the content of a cigarette, the effects of smoking behavior, and efforts to prevent smoking behavior, so that children can understand the concept of material learned together. In the next stage, children do active learning in groups by developing thinking skills and increasing their understanding of the material learned together with friends or group members. Children are required to understand the content by discussing and motivating each other in groups so that at the end of the activity, all children have good knowledge.

\section{Conclusions}

Based on the results of the above research, it was found that health education using the STAD method can improve one's knowledge. Children will receive the selection of the STAD method as a method of health education in primary school children. This method offers health education that is active among children so that all children can learn together to reach the highest level of knowledge. 


\section{References}

1. Puslitbang. Health risk behaviors in middle and high school students in Indonesia. Research and Development Agency of the Ministry of Health of the Republic of Indonesia [Internet]. 2015;1-116. Available from:

http://www.who.int/ncds/surveillance/gshs/GSHS_2015_Indonesia_Report_Bahasa.pdf? ua $=1$

2. Republic of Indonesia Ministry of Health. The main results of riskesdas 2018. 2018;

3. Republic of Indonesia Ministry of Health. Data Center and Health Information-day without world tobacco. World tobacco-free day. 2015. p. 2-12.

4. Cahn WZ, Drope J, Hamill S, Islami F, Liber A, Nargis N, et al. The tobacco atlas sixth edition. 6th ed. Atlanta: American Cancer Society and Vital Strategies; 2018.

5. Republic of Indonesia Ministry of Health. Basic Health Research, 2013. Minist Heal Repub Indones. 2013;(1):1-303.

6. Cruz GG, Ferrero MB, Coca IA, Maderuelo JÁ, García MT. Program for the prevention of smoking in secondary school students. 2009;45(1):16-23. Available from: http://dx.doi.org/10.1016/S1579-2129(09)71783-5

7. Malcon MC, Menezes AM., Assunção MCF, Neutzling MB, Challal P. Effectiveness of an educational intervention on smoking among school adolescents Efetividade de uma intervenção. 2011;14(1):1-12.

8. Prokhorov A V., Calabro KS, Tamí-Maury I. Nicotine and tobacco use prevention among youth and families. Semin Oncol Nurs [Internet]. 2016;32(3):197-205. Available from: http://dx.doi.org/10.1016/j.soncn.2016.05.003

9. Notoatmodjo. Health Promotion and Health Behavior. Revision. Jakarta: Rineka Cipta; 2012.

10. Suryanto. Health education in elementary schools needs to be prioritized. 2012;2011-2. Available from: http://staff.uny.ac.id/sites/default/files/6. Health education in elementary schools needs to be prioritized ( WUNY, Januari 2012 ).pdf

11. Slavin. Cooperative learning: Theory, research, and practice. Bandung: Nusa Media; 2010.

12. Slavin RE. Cooperative learning in schools [Internet]. Second Edi. Vol. 4, International Encyclopedia of the Social \& Behavioral Sciences: Second Edition. Elsevier; 2015. 881886 p. Available from: http://dx.doi.org/10.1016/B978-0-08-097086-8.92028-2

13. Khan GN. Effect of student's team achievement division (STAD) on academic achievement of students. 2011;7(12):211-5.

14. Tiantong M, Teemuangsai S. Student team achievement divisions (STAD) technique through the moodle to enhance learning achievement. 2013;6(4):85-92.

15. Akhrian Syahidi A, Noor Asyikin A, Asy'Ari. Applying student team achievement divisions (STAD) model on the material of the basic program branch control structure to increase activity and student result. IOP Conf Ser Mater Sci Eng. 2018;336(1).

16. Kriswintari D, Yuanita L, Widodo W. Fostering students ' thinking skill and social attitude through STAD cooperative learning technique on tenth-grade students of chemistry class Fostering students ' thinking skill and social attitude through STAD cooperative learning technique on the tenth gra. 2018;

17. Hanafi A, Basuki I. Student team achievement divisions: Its effect on electrical motor installation knowledge competence. IOP Conf Ser Mater Sci Eng. 2018;336(1).

18. Hiemstra M, Leeuw RNH De, Engels RCME, Otten R. Addictive Behaviors What parents can do to keep their children from smoking: A systematic review on smokingspeci fi c parenting strategies and smoking onset. Addict Behav [Internet]. 2017;70:10728. Available from: http://dx.doi.org/10.1016/j.addbeh.2017.02.003 
19. Yang Z, Floyd K, Tanner JF. Effects of antismoking messages from media on adolescent smoking: The roles of family, school, and culture. J Bus Res [Internet]. 2019;(xxxx):110. Available from: https://doi.org/10.1016/j.jbusres.2019.06.006 